\title{
UTEROTONIC USE IN THE ACTIVE MANAGEMENT OF THIRD STAGE OF LABOR (AMTSL): SYSTEMATIC REVIEW
}

\author{
Noviyati Rahardjo Putri ${ }^{1) *}$, Anis Laela Megasari ${ }^{2)}$ \\ ${ }^{1)}$ Midwifery Department, Medical Faculty, Sebelas Maret University, Ir Sutami Street, No. 36 A, Surakarta, \\ Indonesia \\ 2) Midwifery Study Program, Vocational School Sebelas Maret University; Indonesia
}

*Corresponding author:

Email: novirahardjo@staff.uns.ac.id

\begin{abstract}
Background: Maternal mortality rate in Indonesia has decreased from 184/100,000 live birth (LB) (2016) to 177/100,000 LB (2017), but this number is still high enough than SDGs target of 70/100,000 LB. The one of direct cause of maternal death is hemorrhage, especially postpartum hemorrhage (PPH). Causes of $\mathrm{PPH}$ are uterine atony, laceration of birth canal, resistant placenta and uterine inversion. PPH prevention method is Active Management of Third Stage of Labor (AMTSL). The objective of this systematic review is to analyze the use of uterotonics in AMTSL.

Methods: This systematic review used the PRISMA protocol, articles taken from Google Scholar, Science Direct, and Pub Med. The time span of the research article was 2010 to 2021.

Result: The results of the study describe that the use of uterotonics in single use or combination in third stage of labor can reduce the risk of PPH and shorten the time of the stage. The side effects were reported in misoprostol and methyl ergometrine than oxytocin. In addition, combination therapy with oxytocin and misoprostol can reduce the length of the third stage and the potential for a decrease in hemoglobin within 24 hours of delivery. In Indonesia, if oxytocin is not available, maternal nipple stimulation is performed as nonpharmacological therapy or ergometrine $0.2 \mathrm{mg}$ is given to patients without complications of high blood pressure.
\end{abstract}

Conclusion: The use of uterotonics is adjusted to its cost-effectiveness, ability to store and refrigerate also the benefits compare to the side effects to the patients.

Keywords:active management of the third stage, uterotonics, postpartum, hemorrhage

\section{INTRODUCTION}

Maternal Mortality Rate (MMR) is one of health status's indicator in Indonesia. There is a downward trend in MMR in the world and in Indonesia. In 2017, the world's MMR decreases from 214 (in 2016) to $211 / 100,000$ live birth (LB). In Indonesia, the MMR reached 184 down to $177 / 100,000 \mathrm{LB}$ in the same year period $^{[1]}$. However, the decline of MMR is 
still much higher when compared to Sustainable Development Goals's target (SDGs) in 2030 which is less than $70 / 100,000 \mathrm{LB}^{[2]}$.

The direct causes of MMR globally and in Indonesia are hemorrhage, especially PPH, pre-eclampsia and eclampsia, infections, complications caused by comorbidities disease during childbirth and unsafe abortion. These direct causes contribute $75 \%$ of the causes of $\mathrm{MMR}^{[3,4]}$.

Postpartum hemorrhage is defined as vaginal bleeding of more than $500 \mathrm{ml}$ immediately after delivery of the placenta or $1,000 \mathrm{ml}$ in operative delivery which has the potential to affect the mother's hemodynamics $^{[5]}$. The American College of Obstetrics and Gynecology in 2017 updated the definition of postpartum hemorrhage as vaginal bleeding of more than $1,000 \mathrm{ml}$ or immediately after delivery of the placenta or that has the potential to affect maternal hemodynamics either during vaginal or operative delivery ${ }^{[6]}$.

Some causes of PPH are uterine atony, laceration of the birth canal, placenta resistant and uterine inversion ${ }^{[6]}$. The prevention of postpartum hemorrhage is active management of third stage of labor (AMTSL). AMTSL is a prophylactic intervention recommended by World Health Organization (WHO) since 2007 which consists of: 1) Giving uterotonic immediately after baby is born preferably oxytocin; 2) Controlled cord tension; and 3) uterine massage. The main aspect of the three procedures combined in one step of care is the administration of uterotonics ${ }^{[7]}$.

Uterotonic in AMTSL is a therapy that can increase uterine contraction immediately after the baby's born. Several uterotonics are oxytocin, ergometrine, misoprostol $^{[8]}$. Oxytocin 10 in intramuscular route is first line therapy recommendations of $\mathrm{WHO}^{[7,9]}$. Alternatives therapy when oxytocin is unavailable are ergometrine $0.2 \mathrm{mg}$ intramuscularly, misoprostol $600-900$ mg orally, sub lingually or rectally ${ }^{[9]}$.

Several studies abroad and in Indonesia have begun to compare the effectiveness of each uterotonic in the third stage of labor to present the best results in third stage of labor. This study mainly explored the effectiveness of each uterotonic in single-dose such as oxytocin, methyl ergometrine, misoprostol and the combination of the therapies. Several related systematic reviews also analyzed the use of uterotonics in the third stage of labor, but in this systematic review analyzed the use of uterotonics and the combination on labor outcomes both on bleeding and side effects in mother.

Based on this background, the authors compiled a systematic review to analyze the use of uterotonics in AMSTL.

\section{METHODS}

This systematic review uses the PRISMA protocol (Preferred Reporting Items for Systematic Review and MetaAnalysis Protocols). The articles taken from Google Scholar, Science Direct, and Pub Med. The time span of this articles is latest 10 years; 2011 to 2021. In addition, relevant text books and guidelines were used to add further information or additional reports that were not identified in the electronic search.

The keywords taken from the PICOS technique (Population Intervention Compare Outcome Study design). The keywords of this study are uterotonic or oxytocin or ergometrine or misoprostol and active management of third stage of labor (AMTSL).

The inclusion criteria for those articles are: (1) target group: mothers giving birth, (2) intervention: uterotonics (3) outcome: bleeding or placental detachment or side effect (4) research method: experimental design (5) articles written in English and Indonesian. 
Articles were excluded according to the exclusion criteria, namely (1) incomplete documents, (2) irrelevant (3) not explaining the research method, population, and sampling technique, (4) document duplication (5) articles written in another language of English and Indonesian.

Figure 1 is a prism protocol for determining the number of articles for data extraction. This protocol consists of identification, screening, feasibility and final results.
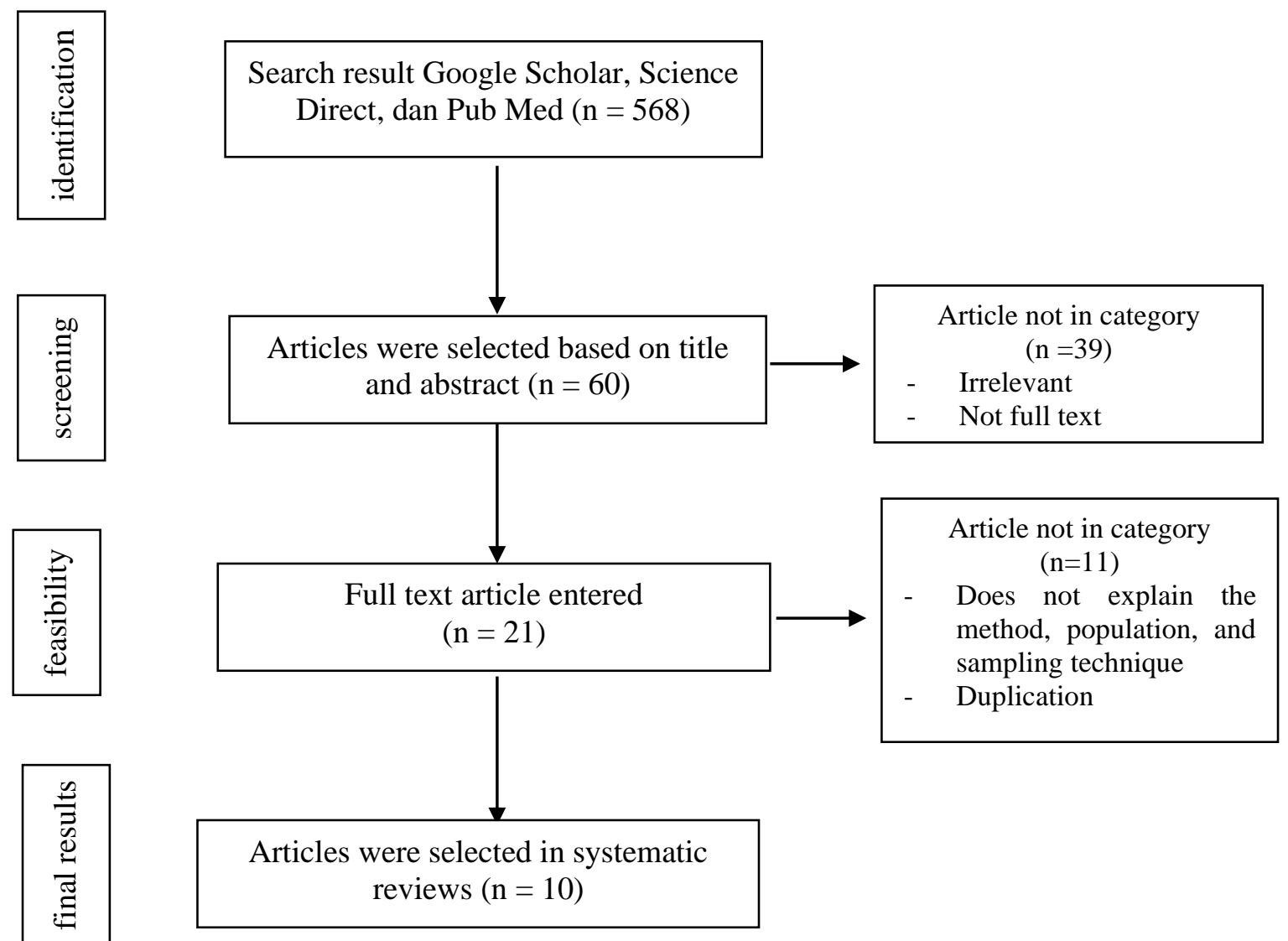

Picture 1. PRISMA Protocol

\section{RESULT}

There are 10 articles which appropriate with inclusion and exclusion criteria. This article will be explained in data extraction table. There are 3 articles compare between AMTSL and expectant management. There are 6 articles describe comparison of the effectiveness of single use doses uterotonics. Uterotonic therapy include oxytocin, methyl ergometrine, misoprostol and carboprost. While 1 article describe the combination of uterotonic therapy in AMTSL. Several 
dependent variables are the average of blood loss during labor, the duration of the third stage, changes in hematocrit, the risk of postpartum hemorrhage and a description of the side effects. The results of the extraction of research articles are presented in table 1. 
Table 1 Extraction of The Articles

\begin{tabular}{|c|c|c|c|c|c|}
\hline No & Main Author Name, Title & Study design & Population & Intervention and comparison & Result Study \\
\hline 1. & $\begin{array}{l}\text { Puti Lenggo Geni, Irwan } \\
\text { Taufiqur Rachman, Heru } \\
\text { Pradjatmo } \\
\text { The Administration of } \\
\text { Misoprostol in Active } \\
\text { Management of the Third } \\
\text { Stage of Labor in Reducing } \\
\text { Postpartum Hemorrage. } \\
2017^{[10]}\end{array}$ & $\begin{array}{l}\text { Blinding } \\
\text { randomized } \\
\text { controlled trial }\end{array}$ & $\begin{array}{l}\text { Total of } 104 \text { mothers during the } \\
\text { third stage of labor, divided into } 2 \\
\text { groups, namely: } \\
\text { 1. Intervention group: } 52 \text { mothers } \\
\text { given misoprostol } 600 \text { mcg } \\
\text { orally } \\
\text { 2. Control group: } 52 \text { mothers } \\
\text { were not given misoprostol } 600 \\
\text { mcg orally }\end{array}$ & $\begin{array}{l}\text { The intervention was } \\
\text { administration of misoprostol } 600 \\
\text { mcg orally in the third stage of } \\
\text { labor combine with AMTSL. } \\
\text { The independent variables were } \\
\text { the average of blood loss during } \\
\text { labor, decreased hemoglobin levels } \\
\text { and hematocrit levels in } 24 \text { hours } \\
\text { postpartum. }\end{array}$ & $\begin{array}{l}\text { Misoprostol administration in AMTSL } \\
\text { method affected in the amount of blood } \\
\text { loss during labor and decreased } \\
\text { hemoglobin levels }(\text { OR } 2.45 ; \rho \text { value }= \\
0.04) \text {, (OR 2.99; } \rho \text { value }=0.01) \text {. } \\
\text { Misoprostol administration had no effect } \\
\text { on decreasing hematocrit levels ( } \rho \text { value }= \\
0.75) \text {. }\end{array}$ \\
\hline 2. & $\begin{array}{l}\text { Revinel, } \\
\text { Comparative Effectiveness } \\
\text { of the Third Stage of Labor } \\
\text { Between Administration of } \\
\text { Rectally Misoprostol and } \\
\text { Oxytocin Intramuscular. } \\
2014^{[11]}\end{array}$ & $\begin{array}{l}\text { Randomized } \\
\text { controlled clinical } \\
\text { trial study }\end{array}$ & $\begin{array}{l}\text { Total of } 60 \text { mothers during the third } \\
\text { stage of labor, divided into } 2 \\
\text { groups, namely; } \\
\text { 1. Intervention group: } 30 \mathrm{mothers} \\
\text { given misoprostol } 600 \mathrm{mg} \text { per } \\
\text { rectal } \\
\text { 2. Control group: } 30 \text { mothers with } \\
10 \text { iu of intramuscular oxytocin. }\end{array}$ & $\begin{array}{l}\text { The intervention was the } \\
\text { administration of misoprostol } 600 \\
\text { mg per rectal in the third stage of } \\
\text { labor. } \\
\text { The independent variables were } \\
\text { the duration of third stage of labor } \\
\text { and the amount of bleeding up to } 2 \\
\text { hours postpartum. }\end{array}$ & $\begin{array}{l}\text { There is an effect of administration } \\
\text { misoprostol rectally on the duration of } \\
\text { third stage of labor and the amount blood } \\
\text { loss during labor above } 150 \mathrm{ml} \text {. } \\
\text { The average of duration of third stage of } \\
\text { labor misprostol } 600 \mathrm{mgr} \text { rectally vs. } \\
\text { oxytocin } 10 \mathrm{iu} \text { intramuscularly are } 5.7 \\
\text { minutes vs. } 9.7 \text { minutes. } \\
\text { Mean amount of bleeding } 2 \text { hours } \\
\text { postpartum with misprostol } 600 \mathrm{mgr} \\
\text { rectally vs oxytocin } 10 \mathrm{iu} \\
\text { intramuscularly; } 153.3 \mathrm{cc} \text { vs } 187.7 \mathrm{cc} \text {. }\end{array}$ \\
\hline 3. & $\begin{array}{l}\text { Yusran Antonius, Eddy } \\
\text { Hartono, Umar Malinta. } \\
\text { Comparison of Bleeding } \\
\text { Amount and Length of } \\
\text { Third Stage of Labor Using } \\
\text { Sublingual Misoprostol with } \\
\text { Intramuscular Oxytocin in } \\
\text { Grandemultipara. 2011 } \\
\text { [12] }\end{array}$ & $\begin{array}{l}\text { Randomized } \\
\text { clinical trial }\end{array}$ & $\begin{array}{l}\text { Total of } 70 \text { mothers during the third } \\
\text { stage of labor, divided into } 2 \\
\text { groups: } \\
\text { 1. Intervention group: } 35 \text { mothers } \\
\text { given misoprostol } 400 \text { mcg } \\
\text { sublingual } \\
\text { 2. Control group: } 35 \text { mothers given } \\
\text { oxytocin } 10 \text { iu intramuscularly. }\end{array}$ & $\begin{array}{l}\text { The intervention was the } \\
\text { administration of misoprostol } 400 \\
\text { mcg sublingually in the third stage } \\
\text { of labor. } \\
\text { The independent variables were } \\
\text { the duration of third stage of labor } \\
\text { and the amount of blood loss } \\
\text { during labor. }\end{array}$ & $\begin{array}{l}\text { There was a significant difference in the } \\
\text { duration of third stage of labor. The } \\
\text { misoprostol } 400 \mathrm{mcg} \text { sublingual group } \\
\text { had a shorter duration of third stage of } \\
\text { labor with a mean } \pm \mathrm{SD} ; 9.09 \pm 2.15 \text { minute } \\
\text { compared to oxytocin group of } \\
10.45 \pm 2.26 \text { minute }(\rho \text { value }=0.012) \text {. } \\
\text { The amount of blood loss was less in the } \\
\text { sublingual } 400 \mathrm{mcg} \text { misoprostol group } \\
\text { with a mean } \pm S D ; 190.73 \pm 18.91 \text { ml } \\
\text { compared to oxytocin group }\end{array}$ \\
\hline
\end{tabular}




\begin{tabular}{|c|c|c|c|c|c|}
\hline & & & & & $\begin{array}{l}220.24 \pm 39.27 \mathrm{ml}, \rho \text { value }=0.000) \\
\text { There was no relationship between the } \\
\text { use of both therapies with side effects }(\rho \\
\text { value }=0.098) \text {. }\end{array}$ \\
\hline 4. & $\begin{array}{l}\text { Mukta Mani, Sahay Priti } \\
\text { Bala } \\
\text { Role of Misoprostol } 600 \\
\text { mcg Oral in Active } \\
\text { Management of Third Stage } \\
\text { of Labor: A Comparative } \\
\text { Study with Oxytocin } 10 \text { IU } \\
\text { im.2013 }\end{array}$ & $\begin{array}{l}\text { Randomized } \\
\text { clinical trial }\end{array}$ & $\begin{array}{l}\text { Total of } 200 \text { mothers during the } \\
\text { third stage of labor, divided into } 2 \\
\text { groups: } \\
\text { 1. Intervention group: } 100 \\
\text { mothers given misoprostol } 600 \\
\text { mcg orally } \\
\begin{array}{l}\text { 2. Control group: } 100 \text { mothers } \\
\text { given oxytocin } 10 \text { iu } \\
\text { intramuscularly. }\end{array}\end{array}$ & $\begin{array}{l}\text { The intervention was the } \\
\text { administration of misoprostol } 600 \\
\text { mcg orally in the third stage of } \\
\text { labor. } \\
\text { The independent variables were } \\
\text { the duration of third stage of labor, } \\
\text { the amount of blood loss during } \\
\text { labor and the decrease in } \\
\text { hemoglobin levels. }\end{array}$ & $\begin{array}{l}\text { There was no difference in the effect of } \\
\text { misoprostol } 600 \text { mcg orally and oxytocin } \\
10 \text { iu intramuscularly. } \\
\text { In the intervention group; the mean the } \\
\text { amount of blood loss during labor was } \\
145 \mathrm{ml} \text {, the mean duration of third stage } \\
\text { of labor } 3.76 \text { minutes and the decrease in } \\
\text { hemoglobin was } 0.55 \mathrm{~g} / \mathrm{dl} \text {. } \\
\text { In the control group; the mean the amount } \\
\text { of blood loss during labor was } 125.6 \mathrm{ml} \text {, } \\
\text { the mean duration of third stage of labor } \\
3.50 \text { minutes and the decrease in } \\
\text { hemoglobin was } 0.48 \mathrm{~g} / \mathrm{dl} \text {. }\end{array}$ \\
\hline 5. & $\begin{array}{l}\text { Thibaud Quibel, Idir Ghout, } \\
\text { François Goffinet, Laurent } \\
\text { J. Salomon, Julie Fort, } \\
\text { Sophie Javoise, Laurence } \\
\text { Bussieres, Philippe } \\
\text { Aegerter, and Patrick } \\
\text { Rozenberg. } \\
\text { Active Management of the } \\
\text { Third Stage of Labor with a } \\
\text { Combination of Oxytocin } \\
\text { and Misoprostol to Prevent } \\
\text { Postpartum Hemorrhage. } \\
\text { 2016 }\end{array}$ & $\begin{array}{l}\text { Randomized } \\
\text { controlled trial }\end{array}$ & $\begin{array}{l}\text { Total of } 1,605 \text { mothers during the } \\
\text { third stage of labor, divided into } 2 \\
\text { groups: } \\
\text { 1. The intervention group: } 806 \\
\text { mothers with oxytocin } 10 \text { iu } \\
\text { intravenously plus misoprostol } \\
400 \text { mcg orally } \\
\text { 2. The control group: } 799 \text { mothers } \\
\text { with } 10 \text { iu intravenous oxytocin } \\
\text { plus a placebo. }\end{array}$ & $\begin{array}{l}\text { The intervention was the } \\
\text { administration of misoprostol } 400 \\
\text { mcg orally and oxytocin } 10 \text { iu } \\
\text { intravenously. } \\
\text { The independent variables were } \\
\text { the amount of blood loss during } \\
\text { labor and secondary postpartum } \\
\text { hemorrhage ( } 24 \text { hours). }\end{array}$ & $\begin{array}{l}\text { There was no effect due to administration } \\
\text { misoprostol } 400 \text { mcg orally and oxytocin } \\
10 \text { iu intravenously compared to placebo } \\
\text { and oxytocin } 10 \text { iu intravenously on } \\
\text { AMTSL on blood loss during labor and } \\
\text { secondary postpartum hemorrhage (24 } \\
\text { hours). }\end{array}$ \\
\hline 6. & $\begin{array}{l}\text { Olkamien, } \\
\text { Comparison of active vs } \\
\text { expectant management at } \\
\text { Sinar Kasih Hospital } \\
\text { Tentena. 2014 }{ }^{[15]}\end{array}$ & $\begin{array}{l}\text { Randomized } \\
\text { controlled trial }\end{array}$ & $\begin{array}{l}\text { Total of } 128 \text { mothers during the } \\
\text { third stage of labor, divided into } 2 \\
\text { groups: } \\
\text { 1. The intervention group: } 64 \\
\text { mothers with active management } \\
\text { of third stage of labor. }\end{array}$ & $\begin{array}{l}\text { The intervention was Active } \\
\text { Management of Third Stage of } \\
\text { Labor (AMTSL). } \\
\text { The independent variable was the } \\
\text { duration of third stage of labor. }\end{array}$ & $\begin{array}{l}\text { Active Management of Third Stage of } \\
\text { Labor (AMTSL) shortens the third stage } \\
\text { of labor; } 11.6 \pm 3.5 \text { minutes compared to } \\
\text { expectant management; } 18.7 \pm 3.7 \text { minutes } \\
\text { with } \rho \text { value }<0,05 \text {. }\end{array}$ \\
\hline
\end{tabular}




\begin{tabular}{|c|c|c|c|c|c|}
\hline & & & $\begin{array}{l}\text { 2. The control group: } 64 \text { mothers } \\
\text { with expectant management of } \\
\text { third stage of labor. }\end{array}$ & & \\
\hline 7. & $\begin{array}{l}\text { Kavita A. Chandnani, } \\
\text { Deepti D Sharma. } \\
\text { Third stage of labour: } \\
\text { expectant versus active } \\
\text { management - a } \\
\text { comparative study in local } \\
\text { low risk population.2019 }\end{array}$ & $\begin{array}{l}\text { Prospective } \\
\text { comparative study }\end{array}$ & $\begin{array}{l}\text { Total of } 200 \text { mothers during the } \\
\text { third stage of labor, divided into } 2 \\
\text { groups: } \\
\text { 1. Group A: } 100 \text { mothers with } \\
\text { expectant management of third } \\
\text { stage of labor. } \\
\text { 2. Group B: } 100 \text { mothers with } \\
\text { active management of third } \\
\text { stage of labor. }\end{array}$ & $\begin{array}{l}\text { Group A is the group with } \\
\text { expectant management of third } \\
\text { stage of labor intervention and } \\
\text { group B is the group with active } \\
\text { management of third stage of } \\
\text { labor. } \\
\text { The independent variable was the } \\
\text { duration of the third stage of labor } \\
\text { and the amount of blood loss. }\end{array}$ & $\begin{array}{l}\text { The average volume of blood loss in } \\
\text { group A was } 360.5 \mathrm{ml} \text { and group B was } \\
290.6 \mathrm{ml} \text {. } \\
\text { In group A: } 12 \text { patients have a blood loss } \\
\text { more than } 500 \mathrm{ml} \text { of blood. } \\
\text { In group B, } 66 \% \text { of patient had the } \\
\text { duration of the third stage of labor less } \\
\text { than } 5 \text { minutes compared to group A, } \\
\text { which was only } 22 \% \text {. } \\
\text { The average duration of the third stage of } \\
\text { labor in group A was } 13.46 \pm 8.3 \text { minutes } \\
\text { and group B } 5.32 \pm 3.05 \text { minutes. } \\
\text { Active management of the third stage of } \\
\text { labor can reduce the amount of blood loss } \\
\text { and shorten the duration of the third stage } \\
\text { also can reduce the potential for } \\
\text { postpartum hemorrhage. }\end{array}$ \\
\hline 8. & $\begin{array}{l}\text { Ajantha Boopathi, Sujir } \\
\text { Radhakrishnan Nayak, Arun } \\
\text { Rao, Bharathi Rao. } \\
\text { Oxytocin } \\
\text { Methylergometrine in the } \\
\text { Active Management of } \\
\text { Third Stage } \\
\text { Labour.2014 }\end{array}$ & $\begin{array}{l}\text { Prospective } \\
\text { comparative study }\end{array}$ & $\begin{array}{l}\text { Total of } 300 \text { mothers during labor, } \\
\text { divided into } 2 \text { groups: } \\
\text { 1. Group A: } 150 \text { mothers given } \\
10 \text { iu intramuscular oxytocin } 1 \\
\text { minute after birth. } \\
\text { 2. Group B: } 150 \text { mothers given } \\
\text { intravenous injection of methyl } \\
\text { ergometrine } 0.5 \mathrm{mg} \text { in the } \\
\text { delivery of the baby's anterior } \\
\text { shoulder. }\end{array}$ & $\begin{array}{l}\text { The independent variables were } \\
\text { the duration of the third stage of } \\
\text { labor, blood loss, decreased } \\
\text { incidence of postpartum } \\
\text { hemorrhage, effects on hematocrit, } \\
\text { blood pressure and side effects. }\end{array}$ & $\begin{array}{l}\text { The duration of the third stage of labor } \\
\text { was shorter in group B }(2.31 \pm 1.06 \\
\text { minutes) than in group A }(3.45+2.75) \text {. } \\
\text { The mean blood loss of labor in group B } \\
\text { was less }(149.33 \pm 145.47 \mathrm{ml}) \text { than group } \\
\text { A }(196.57 \pm 192.30) \text {, with } \rho \text { value } \\
<0.0001 \text {. } \\
\text { The risk of primary postpartum } \\
\text { hemorrhage (PPH) was lower in group B } \\
\text { than group A. } \\
\text { The perceived side effects; nausea and } \\
\text { vomiting were significant in group B who } \\
\text { received intravenous injection of } 0.5 \text { mg } \\
\text { methyl ergometrine with } \rho \text { value }<0.001 \text {. }\end{array}$ \\
\hline 9. & $\begin{array}{l}\text { Pradnya A. Supe, Shailesh } \\
\text { J. Kore, Y. S. Nandanwar. }\end{array}$ & $\begin{array}{l}\text { Prospective } \\
\text { comparative study }\end{array}$ & $\begin{array}{l}\text { Total of } 200 \text { mothers during the } \\
\text { delivery of the baby's anterior }\end{array}$ & \begin{tabular}{|lrrr|} 
This study & \multicolumn{2}{c}{ compared } & 3 \\
interventions; & $800 \quad \mathrm{mcg}$ & of \\
\end{tabular} & $\begin{array}{l}\text { There was no difference between four } \\
\text { groups in this study, but the mean }\end{array}$ \\
\hline
\end{tabular}

Copyright @ 2022, Placentum: Jurnal Ilmiah Kesehatan dan Aplikasinya, ISSN 2303-3746, e ISSN 2620-9969 


\begin{tabular}{|c|c|c|c|c|c|}
\hline & $\begin{array}{l}\text { A Comparative Study of } \\
\text { Efficacy of Misoprostol } \\
\text { With Methyl Ergometrine } \\
\text { and Carboprost In Active } \\
\text { Management of Third Stage } \\
\text { of Labour.2016 }\end{array}$ & & $\begin{array}{l}\text { shoulder, divided into } 4 \text { groups: } \\
\text { 1. Group A: } 25 \text { mothers given } \\
800 \text { mcg misoprostol rectally. } \\
\text { 2. Group B: } 25 \text { mothers given } \\
\text { intravenous injection of methyl } \\
\text { ergometrine } 0.5 \mathrm{mg} \\
\text { 3. Group C: } 25 \text { mothers given } 125 \\
\text { mcg carboprost } \\
\text { 4. Group D: } 25 \text { mothers as control } \\
\text { group. }\end{array}$ & $\begin{array}{l}\text { misoprostol rectally, injection of } \\
\text { methyl ergometrine } 0.2 \mathrm{mg} \\
\text { intravenously and } 125 \mathrm{mcg} \text { of } \\
\text { carboprost. } \\
\text { The independent variables were } \\
\text { duration of the third stage of labor } \\
\text { and the amount of blood loss. }\end{array}$ & $\begin{array}{l}\text { duration of the third stage of labor was } \\
\text { the shortest in group A (misoprostol } 800 \\
\text { mcg); } 8.88 \pm 5.0 \text { minutes. Group B } \\
8.96 \pm 3.6 \text { minutes, group C } 8.90 \pm 3.59 \\
\text { minutes and group D } 9.56+4.63 \text { minutes. } \\
\text { There was a difference in the mean blood } \\
\text { loss during delivery with value }<0.001 \\
\text { where group A had the least amount of } \\
124.40+34.7 \mathrm{ml} \text {, compared to group B } \\
152.20+49.3 \mathrm{ml} \text {, group C } 153.80+43.7 \mathrm{ml} \\
\text { and group C. D } 167.40+52.9 \mathrm{ml} \text {. } \\
\text { Descriptions of side effects are shivering } \\
\text { cause of misoprostol, pain in the abdomen } \\
\text { cause of methyl ergometrine and } \\
\text { vomiting and diarrhea cause of } \\
\text { carboprost. }\end{array}$ \\
\hline 10. & $\begin{array}{l}\text { Abubaker Y. H. Abdel } \\
\text { Rahim, Mohamed A. A } \\
\text { Gadir E. Ounsa, Rayan G. } \\
\text { Albarakati, Elsadig Y. } \\
\text { Mohamed, Sawsan M. } \\
\text { Abdalla. } \\
\text { Comparison } \\
\text { Oxytocin, Ergometrine And } \\
\text { Misoprostol In Active } \\
\text { Management of The Third } \\
\text { Stage of Labour: A } \\
\text { Randomized Controlled } \\
\text { Trial.2019 }\end{array}$ & $\begin{array}{l}\text { Randomized } \\
\text { controlled trial }\end{array}$ & $\begin{array}{l}\text { Total of } 150 \text { mothers during the } \\
\text { delivery of the baby's anterior } \\
\text { shoulder, divided into } 3 \text { groups: } \\
\text { 1. Group A: } 50 \text { mothers given } 400 \\
\text { mcg of sublingual misoprostol. } \\
\text { 2. Group B: } 50 \text { mothers given } 10 \\
\text { iu intravenous infusion of } \\
\text { oxytocin. } \\
\text { 3. Group C: } 50 \text { mothers given } \\
\text { intravenous infusion of metyl } \\
\text { ergometrine. }\end{array}$ & $\begin{array}{l}\text { This study compared } 3 \\
\text { intervention: } 400 \text { mcg of } \\
\text { sublingual misoprostol, } 10 \text { iu of } \\
\text { intravenous infusion oxytocin dan } \\
0.5 \mathrm{mg} \text { of intravenous infusion of } \\
\text { methyl ergometrine } 0,5 \mathrm{mg} \text {. } \\
\text { The independent variables were } \\
\text { duration of the third stage of labor } \\
\text { and the amount of blood loss. }\end{array}$ & $\begin{array}{l}\text { The shortest duration of third stage of } \\
\text { labor: group A who received misoprostol } \\
400 \text { mcg sublingually }(3.89 \pm 0.37 \\
\text { minutes), group B oxytocin }(4.6 \pm 0.9 \\
\text { minutes) and group C Methyl } \\
\text { Ergometrine }(5.45 \pm 0.9 \text { minutes). } \\
\text { The average of blood loss in labor were } \\
\text { group A (168.36 } \pm 24.83 \mathrm{ml}) \text {, group B } \\
(205.56 \pm 34.82 \mathrm{ml}) \text { and group C } \\
(214.49 \pm 35.97 \mathrm{ml}) \text {. }\end{array}$ \\
\hline
\end{tabular}




\section{DISCUSSION}

During the third stage of labor, the uterine muscles contract downwards which causes vasoconstriction of the blood vessels that pass through the uterine and placenta, thereby stopping blood flow to the placenta. The cessation of blood flow to the placenta causes detachment of the placenta ${ }^{[20]}$.

Since 2007, the World Health Organization (WHO) has recommended Active Management of Third Stage of Labor (AMTSL) as a method to prevent the risk of PPH. (AMTSL) is one of the innovation to replace expectant management. Expectant management is a delivery assistance step which waiting for the natural signs of placental separation, clamping the umbilical cord after it does not beat and giving uterotonics when uterine atony occurs ${ }^{[7]}$.

AMTSL consists of administration of uterotonic as the main component, controlled tension of the umbilical cord and uterine massage ${ }^{[7]}$. Uterotonic in AMTSL intends the increase of uterine contractions to prevent incidence of uterine atony. The first line uterotonic administration is oxytocin 10 iu intra muscular within 1 minute after birth.

Several studies have concluded that AMTSL can reduce the amount of blood loss and duration of third stage of labor less than 5 minutes compared with expectant management ${ }^{[16]}$. Study in Indonesia concluded that AMTSL proven shorten the duration of the third stage of labor: $11.6 \pm 3.5$ minutes compared to expectant management: $18.7 \pm 3.7$ minutes $^{[15]}$.

Research study also conclude that the AMTSL has side effects, including; increase in diastolic blood pressure, nausea and vomiting after childbirth, abdominal pain and an increase used of analgesics $^{[20]}$. But the benefits of uterotonics are more important than side effects so that every pregnant woman is communicated about the side effects that will be felt by the mother due to the administration of uterotonics ${ }^{[21]}$.

However, in the context of preventing $\mathrm{PPH}$, which is mostly caused by uterine atony, AMTSL is a recommended procedure by the WHO. Uterotonic expected to stimulate uterine contractions so as to shorten the duration of third stage of labor and reduce blood $\operatorname{loss}^{[7,20]}$. Uterotonic in AMTSL included:

1. Oxytocin

Oxytocin is one of the most widely used uterotonic types ${ }^{[8]}$. The oxytocin injection is unstable at room temperature and require cold transport in distribution. However, storage is not in frozen conditions ${ }^{[8,22]}$.

Oxytocin can increase the frequency, amplitude, and duration of uterine contractions. The mechanism of oxytocin as a uterotonic is stimulate inositol triphosphate and an increasing of intracellular calcium in the myometrium. Calcium ions in myometrium stimulate bind calmodulin and activate myosin light chain kinase which is the core mechanism of uterine smooth muscle contraction $^{[23]}$.

At low doses, oxytocin can stimulate rhythmic uterine contractions and prevent bleeding. However, at high doses it will cause a persistent tetanic uterine contractions. Intravenous administration by infusion can be used to maintain uterine contractions with a response time of 35 minutes after administration. Through the intramuscular route, oxytocin can maintain uterine contraction activity for up to $2-3$ hours with a response time of $2-5$ minutes after the initial administration $^{[8]}$. Administration of intravenous oxytocin cause major side 
effects including severe hypotension, tachycardia and dysrhythmias ${ }^{[23]}$.

Administration of oxytocin 10 iu in intramuscular route is one of the main recommendations of $\mathrm{WHO}^{[7,9]}$. Administration of oxytocin as first line therapy in AMTSL because it proven have no any side effects compared to other types of uterotonics ${ }^{[17]}$.

2. Methyl Ergometrine

Methyl ergometrine is a uterotonic that can increase uterine muscle tone at low doses, while at high doses this therapy causes uterine tetany contraction. The ergot alkaloids in methyl ergometrine increase vasoconstriction and stimulation of central dopamine receptors. These compounds interact with alpha adrenergic receptors in the myometrium. This stimulates the entry of calcium into the myometrial cells causing contraction ${ }^{[24]}$.

Ergot alkaloids in methyl ergometrine stimulates acute coronary vasospasm or myocardial infarction so it is not recommended to hypertension, pre-eclampsia and cardiac malfunction. The administration should be assessed that the benefits outweigh the possible risks ${ }^{[25]}$.

As an uterotonic, methyl ergometry can be an alternative to shorten the third stage of labor, reducing the risk of blood loss and postpartum hemorrhage. Research in India described the use of methyl ergometrine to be more effective in AMTSL than oxytocin. However, the study also noted that there were significant side effects in the group receiving methyl ergometrine ${ }^{[17]}$.

3. Misoprostol

Misoprostol is a prostaglandin E1 analogue licensed for the treatment of peptic ulcers. However, the benefits of "off label" misoprostol are used in obstetrics as a uterotonic ${ }^{[8,26]}$.
Misoprostol wrapped in aluminum oil packaging, soluble in water, stable in heat and do not require cold temperatures and affordable prices. This performance placing misoprostol as a uterotonic alternative in areas with low resources ${ }^{[8,13]}$. Recommendation doses of misoprostol is $600 \mathrm{mcg}$ orally ${ }^{[22]}$.

Misoprostol can be given orally, sublingually, vaginally and rectally. The oral and sublingual pathways have a rapid onset of time, while the vaginal and rectal routes produce the longest therapeutic activity ${ }^{[8]}$.

Several studies compared the effectiveness of oxytocin 10 iu intramuscularly with misoprostol in AMTSL with the main indicators the duration of the third stage of labor, the amount of blood loss and a decrease in hemoglobin levels ${ }^{[11-13,19]}$. In addition, the side effects of therapy are also concluded by several studies as one way to obtain effective and efficient therapy but is safe for patients ${ }^{[11,12]}$. A study with a larger sample size in India involving 200 mothers in the third stage of labor concluded that there was no statistically significant difference in the duration of the third stage of labor and a decrease in hemoglobin 24 hours postpartum in misoprostol $600 \mathrm{mcg}$ orally group and oxytocin 10 iu intramuscular group. The third stage duration was reduced only 20 seconds and bleeding was reduced by about $20 \mathrm{cc}$ in misoprostol group $^{[13]}$.

A systematic review that focused on the effectiveness of preventing postpartum hemorrhage concluded that the misoprostol group had PPH incident lower than the oxytocin group. However, the incidence of misoprostol side effects was felt by more patients compared to the oxytocin group. Commonly side 
effects are nausea, vomiting and shivering ${ }^{[28]}$.

Based on recommendations from WHO and the Ministry of Health in Indonesia, first line uterotonic prophylaxis in AMTSL is oxytocin 10 iu intramuscularly ${ }^{[5,7]}$. In the Ministry of Health of Indonesia's guidelines (2013), if there is no oxytocin, The mother's nipple stimulation used to produce natural oxytocin. Furthermore, methyl ergometrine $0.2 \mathrm{mg}$ intramuscularly can be given to patients who do not have preeclampsia, eclampsia and hypertension $^{[5]}$. The use of uterotonics is adjusted to its cost-effectiveness, ability to store and refrigerate also the benefits vs side effects to the patients.

\section{CONCLUSION}

Several uterotonics that can be used in AMTSL are oxytocin, ergometrin, misoprostol, carbetocin and carboprost. The first line uterotonic in Indonesia is oxytocin 10 iu intramuscularly. The study concluded that the administration of uterotonics can reduce the duration of third stage of labor and prevent PPH. In addition, side effects after administration of methyl ergometrine and misoprostol were described more than those of oxytocin. Several studies concluded the effectiveness of combination therapy, but also reported the side effects experienced by patients on combination therapy. The use of uterotonics is adjusted to its costeffectiveness, ability to store and the benefits and side effects felt by the mother in labor.

\section{ACKNOWLEDGEMENT}

The authors would like to thank those who helped complete the writing of this article, lecturers at the Midwifery Study Program, Faculty of Medicine and D III Midwifery Study Program, Vocational School, Sebelas Maret University, Surakarta.

\section{BIBLIOGRAPHY}

1. WHO, UNICEF, UNFPA Group, Bank WD, Population the UN. Maternal mortality ratio (modeled estimate, per 100,000 live births) Indonesia [Internet]. https://data.worldbank.org2019;Av ailable from:

https://data.worldbank.org/indicator /SH.STA.MMRT?locations=ID

2. INFID. Tujuan SDGs [Internet]. https://www.sdg2030indonesia.org/ 2017; Available from:

https://www.sdg2030indonesia.org/ page/11-tujuan-tiga

3. Sali S. Angka kematian ibu : Faktor penyebab dan upaya penanganannya. Jakarta Pusat:

2019.

4. WHO. Maternal mortality

[Internet].

https://www.who.int/newsroom/fact-sheets/detail/maternalmortality2019; Available from: https://www.who.int/newsroom/fact-sheets/detail/maternalmortality

5. Kemenkes. Buku Saku Pelayanan Kesehatan Ibu Pada Pelayanan Kesehatan Dasar dan Rujukan. Seri I. Jakarta: Kementerian Kesehatan Republik Indonesia; 2013.

6. Wormer KC, Jamil RT, Bryant SB. Acute Postpartum Hemorrhage [Internet]. 2021. Available from: http://www.ncbi.nlm.nih.gov/pubm ed/29763164

7. WHO, USAID, CHIP. Active Management of The Third Stage of Labour : New WHO

Recommendations Help to Focus Implementation [Internet]. WHO2014;Available from: https://www.who.int/reproductiveh ealth/publications/maternal_perinat al_health/new-recommendationsamtsl/en/ 
8. Gallos I, Williams H, Price M, Pickering K, Merriel A, Tobias A, et al. Uterotonic drugs to prevent postpartum haemorrhage: A network meta-analysis. Health Technol. Assess. (Rockv). 2019;23.

9. Leduc D, Senikas V, Lalonde AB, Leduc D, Ballerman C, Biringer A, et al. Active Management of the Third Stage of Labour: Prevention and Treatment of Postpartum Hemorrhage. J. Obstet. Gynaecol. Canada [Internet] 2009;31:980-93. Available from: http://dx.doi.org/10.1016/S17012163(16)34329-8

10. Geni PL, Rachman IT, Pradjatmo H. Peran Penambahan Misoprostol Pada Penatalaksanaan Aktif Kala Tiga Dalam menurunkan Perdarahan Pascapersalinan. J. Kesehat. Reproduksi 2017;4:170-7.

11. Revinel. Comparative Effectiveness of the Third Stage of Labor Between Administration of Rectally Misoprostol and Oxytocin Intramuscular. Pustaka Unpad [Internet] 2014;1-9. Available from:

http://pustaka.unpad.ac.id/wpcontent/uploads/2014/10/RevinelArtikel.pdf

12. Antonius Y, Hartono E, Malinta U. Perbandingan Jumlah Perdarahan dan Lama Kala III Persalinan Menggunakan Misoprostol Sublingual dengan Oksitosin Intramuskular pada Grandemultipara. JST Kesehat. 2011;1:152-7.

13. Mukta M, Sahay PB. Role of Misoprostol $600 \mathrm{mcg}$ Oral in Active Management of Third Stage of Labor: A Comparative Study with Oxytocin 10 IU i.m. J. Obstet. Gynecol. India [Internet] 2013;63:325-7. Available from: http://link.springer.com/10.1007/s1 3224-012-0330-x
14. Quibel T, Ghout I, Goffinet F, Salomon LJ, Fort J, Javoise S, et al. Active Management of the Third Stage of Labor With a Combination of Oxytocin and Misoprostol to Prevent Postpartum Hemorrhage. Obstet. Gynecol. [Internet] 2016;128:805-11. Available from: https://journals.lww.com/00006250 -201610000-00017

15. Olkamien. Perbandingan Managemen Aktif Kala III dan Konvensional di RSU Sinar Kasih Tentena. J. Ilmu Kesehat. 2014;1:750-8.

16. Chandnani KA, Sharma DD. Third stage of labour: expectant versus active management-a comparative study in local low risk population. Int. J. Reprod. Contraception, Obstet. Gynecol. 2019;8:641.

17. Boopathi A, Nayak SR, Rao A, Rao B. Oxytocin versus Methylergometrine in the Active Management of Third Stage of Labour. Open J. Obstet. Gynecol. 2014;04:666-71.

18. Supe P, Kore S, Nandanwar Y. A comparative study of efficacy of misoprostol with methyl ergometrine and carboprost in active management of third stage of labour. Int. J. Reprod.

Contraception, Obstet. Gynecol. 2016;5:1525-31.

19. Rahim AYHA, Ounsa MAAGE, Albarakati RG, Mohamed EY, Abdalla SM. Comparison between oxytocin, ergometrine and misoprostol in active management of the third stage of labour: a randomized controlled trial. Int. J. Reprod. Contraception, Obstet. Gynecol. 2018;7:2076.

20. Begley CM, Gyte GML, Devane D, McGuire W, Weeks A, Biesty LM. Active versus expectant management for women in the third stage of labour. Cochrane Database 
Syst. Rev. 2019;2019.

21. WHO. WHO recommendations: Uterotonics for the prevention of postpartum haemorrhage [Internet]. 2018. Available from: http://apps.who.int/bookorders. $\% 0$ Ahttps://www.who.int/reproductive health/publications/uterotonicspph/en/

22. Lalonde A. Prevention and treatment of postpartum hemorrhage in low-resource settings. Int. J. Gynecol. Obstet. [Internet] 2012;117:108-18. Available from: http://doi.wiley.com/10.1016/j.ijgo. 2012.03.001

23. Adi Kusuma M, Wiryana M, Hariyasa Sanjaya IN, Widnyana IMG. Perbandingan Efek Oksitosin Bolus 3 IU, 5 IU, dan 10 IU Terhadap Kontraksi Uterus dan Respon Kardiovaskular Pada Seksio Sesarea dengan Anestesi Blok Subaraknoid. Medicina (B. Aires). 2014;44:143-9.

24. Müller-Schweinitzer E, Tapparelli C. Methylergometrine, an Active Metabolite of Methysergide. Cephalalgia [Internet] 1986;6:3541. Available from: http://journals.sagepub.com/doi/10. 1046/j.1468-2982.1986.0601035.x

25. Cuppett CD, Caritis SN. Uterine Contraction Agents and Tocolytics [Internet]. In: Clinical Pharmacology During Pregnancy. Elsevier; 2013. page 30730.Available from: https://linkinghub.elsevier.com/retri eve/pii/B9780123860071000192

26. Desrini S. The benefit and Risk Of Misoprostol Use : in Obstetrics and Gynecology. J. Kedokt. dan Kesehat. Indones. 2015;7:25-9.

27. Gallos I, Williams H, Price M, Merriel A, Gee H, Lissauer D, et al. Uterotonic agents for preventing postpartum haemorrhage : a network meta-analysis ( Review ) SUMMARY OF FINDINGS FOR THE MAIN COMPARISON. Cochrane Database Syst. Rev. 2018;

28. Bilgin Z, Kömürcü N. Comparison of the effects and side effects of misoprostol and oxytocin in the postpartum period: A systematic review. Taiwan. J. Obstet. Gynecol. [Internet] 2019;58:748-56. Available from: https://linkinghub.elsevier.com/retri eve/pii/S1028455919302098 